\title{
Establishment and optimization of ISSR and SAMPL molecular markers as a tool for breeding programs of Pinus radiata
}

\author{
Establecimiento y optimización de marcadores moleculares ISSR y SAMPL como una herramienta \\ para programas de mejoramiento de Pinus radiata
}

\author{
Priscila Moraga-Suazo a ${ }^{\text {, Rodrigo Hasbún }}{ }^{\text {}}$, Claudio Balocchi c and Sofía Valenzuela ${ }^{\text {a* }}$ \\ *Corresponding author: ${ }^{a}$ Universidad de Concepción, Centro de Biotecnología and Facultad de Ciencias Forestales, \\ casilla 160-C, Concepción, Chile, tel.: 56-41-2203850, sofvalen@udec.cl \\ ${ }^{\mathrm{b}}$ Genómica Forestal S. A. Casilla 160-C, Concepción, Chile. \\ ${ }^{\mathrm{c}}$ BIOFOREST, Camino a Coronel, km 15, Concepción, Chile.
}

\begin{abstract}
SUMMARY
Pinus radiata is a conifer of recognized economic value. Studies at genetic and molecular level to support breeding programs of radiata pine have been conducted with difficulty due to its large and complex genome. The development of molecular markers has allowed performing studies on genetic variation, identification of clones and construction of linkage maps. In order to increase the genetic molecular markers in P. radiata, two inter simple sequence repeat (ISSR) markers and twelve selective amplifications of microsatellite polymorphic loci (SAMPL) primer combinations were tested, using a first-generation full-sib family of 86 individuals. Polymerase chain reaction (PCR) products were visualized by capillary electrophoresis and polymorphism was detected by presence or absence of a particular fragment in one P. radiata parental. A total of 18 polymorphic fragments were found for two ISSR primers tested, with an average segregation distortion of $33 \%$. SAMPL markers yielded 85 polymorphic fragments with eight primer combinations, with an average of $22.3 \%$ segregation distortion. Both methodologies showed a good reproducibility, with easy implementation and useful for genetic analysis on $P$. radiata.
\end{abstract}

Key words: capillary electrophoresis, segregation distortion, forest trees.

\section{RESUMEN}

Pinus radiata es una conífera de reconocido valor económico, en la cual los estudios a nivel genético y molecular, han sido conducidos con dificultad en programas de mejoramiento debido a su genoma complejo y de gran tamaño. El desarrollo de marcadores moleculares ha permitido realizar estudios de variación genética, validar clones y construir mapas de ligamiento. Para lograr incrementar la disponibilidad de marcadores moleculares en $P$. radiata, se examinaron dos marcadores ISSR (inter simple sequence repeat) y 12 combinaciones de partidores SAMPL (selective amplification of microsatellite polymorphic loci), usando una familia F1 de 86 hermanos completos de primera generación. Los productos de PCR (polymerase chain reaction) se visualizaron mediante electroforesis capilar y la selección de fragmentos polimórficos se efectuó a base de la presencia o ausencia de un fragmento en uno de los parentales de la familia de $P$. radiata. Un total de 18 fragmentos polimórficos fueron encontrados para los dos partidores ISSR, con una distorsión de segregación promedio de $33 \%$. Los marcadores SAMPL generaron 85 fragmentos polimórficos empleando ocho combinaciones, con un promedio de 22,3 \% de distorsión de segregación. Ambas metodologías mostraron buena reproducibilidad, fácil implementación y utilidad para análisis genético en $P$. radiata.

Palabras clave: electroforesis capilar, distorsión de segregación, especies forestales.

\section{INTRODUCTION}

Pinus radiata D. Don is an economically important species among conifers, recognized by its versatility for different production objectives (Wilcox et al. 2001, Plomion et al. 2007). Many P. radiata breeding programs have been developed, generating genetic gain and increasing the use of clonal silviculture (Sorensson and Shelbourne 2005). Given the complexity and large genome size of pines, more than $42 \mathrm{~Gb} / 2 \mathrm{n}$ (Plomion et al. 2007), detailed genetic and molecular studies have been carried out with difficulty. A possible solution to this is the use of molecular markers for DNA polymorphism exploration and detection (Wilcox et al. 2001, Semagn et al. 2006). Polymorphic information, mode of inheritance, genomic size and complexity are factors that influence the development of a particular technique and the selection of informative molecular markers (Plomion et al. 2007). Among the molecular techniques implemented for $P$. radiata are restriction fragment length polymorphism (RFLP; Devey et al. 2004), random amplified polymorphic DNA (RAPD; Kuang et al. 1999, Wilcox et al. 2001), amplified fragment 
length polymorphism (AFLP; Wilcox et al. 2001), simple sequence repeat (SSR; Fisher et al. 1998, Devey et al. 2002, Chagné et al. 2004) and single-nucleotide polymorphism (SNP; Dillon et al. 2010).

Some molecular marker techniques that are not available currently for $P$. radiata include ISSR and SAMPL markers. ISSR markers are dominant and the primer used for polymerase chain reaction consists of a microsatellite sequence ligated to the $5^{\prime}$ or $3^{\prime}$ ends of the deoxyribonucleic acid (DNA) (Zietkiewicz et al. 1994). SAMPL markers are dominant. DNA is prepared in the same way as for an amplified fragment length polymorphism assay, allowing the use of the same pre-amplified samples, but changing the primer used in the selective amplification for a microsatellite sequence (Morgante and Vogel 1994). The source of polymorphism for both markers is given by the presence or absence of an amplified fragment of particular length between different individuals, which is mainly due to the sequence variation in the primer annealing sites and/or the presence or loss of a restriction site (Semagn et al. 2006).

Both methodologies amplify products from multiple loci and have been successfully used for genotyping (Paglia and Morgante 1998, Bornet and Branchard 2001, Lin et al. 2010), genetic linkage maps (Paglia et al. 1998, Arcade et al. 2000), genetic diversity (Davila et al. 2007, Okun et al. 2008) and somaclonal variation (Leroy et al. 2000), on different species such as European and Japanese larch, Eucalyptus grandis, Phyllostachys and Agave species, among others.

In order to increase the molecular tools available to obtain genetic information in $P$. radiata, the present study suggests that ISSR and SAMPL markers can be useful for genetic analyses in breeding programs. Therefore our goal is to implement both techniques and evaluate segregation distortion in one family of $P$. radiata cultivated in Chile.

\section{METHODS}

Plant material and DNA extraction. An 86 full-sib family (F1) of $P$. radiata was used for the genotyping analysis. Needles from the offspring, parents (XO and XP) and a control sample of Pinus tecunumanii Eguiluz et Perry were collected and DNA was extracted using the DNeasy Plant Mini kit (QIAGEN囚). DNA concentration was determined by spectrophotometry (NanoDrop ND1000, Cellygent). DNA samples were stored at $-20^{\circ} \mathrm{C}$ until used.

Molecular markers. ISSR3 (5' AGAGAGAGAGAGAGAGYC 3') and ISSR6 (5' GAGAGAGAGAGAGAGAYG 3') primers were employed for amplification. Samples were amplified using $10 \mathrm{ng}$ of genomic DNA, $0.2 \mathrm{mM}$ of dNTPs, 1.25 to $1.5 \mathrm{mM}$ of $\mathrm{MgCl}_{2}, 0.25 \mu \mathrm{M}$ of primer, $0.5 \mathrm{U}$ of Taq polymerase and 1x PCR buffer in $20 \mu \mathrm{L}$ total volume. Polymerase chain reaction amplification reactions were performed in a 96-well thermal cycler (GeneAmp PCR System $9700 \mathrm{ABI}$ ) with an initial denaturation of
2 min at $94{ }^{\circ} \mathrm{C}, 35$ cycles of $45 \mathrm{~s}$ each at $94{ }^{\circ} \mathrm{C}, 30 \mathrm{~s}$ at 40 to $52^{\circ} \mathrm{C}, 1 \mathrm{~min}$ at $72{ }^{\circ} \mathrm{C}$, and a final step of $5 \mathrm{~min}$ at $72{ }^{\circ} \mathrm{C}$. The PCR factors that were examined for ISSR 3 and ISSR6 were: a) annealing temperature (between 40 and $52{ }^{\circ} \mathrm{C}$ ), b) DNA concentration (10, 20 and $30 \mathrm{ng}$ ), and c) $\mathrm{MgCl}_{2}$ concentration (1.25 to $1.5 \mathrm{mM})$. Polymerase chain reaction products $(5 \mu \mathrm{L})$ were visualized on $1 \%(\mathrm{w} / \mathrm{v})$ agarose gels. ISSR3 (6-FAM) and ISSR6 (VIC) primers contained a fluorescent dye on the 5' end (Applied Biosystems) for in situ PCR product labeling.

SAMPL marker standardization was performed by the procedure described by Costa et al. (2000) with modifications. Briefly, 50 to $100 \mathrm{ng}$ of genomic DNA were digested with $2 \mathrm{U}$ of EcoRI and MseI and specific adapters were ligated using T4 DNA ligase. Pre-amplification was performed with primers based on the adapter sequence plus two nucleotides in each case. An initial denaturation of $94^{\circ} \mathrm{C}$ for $4 \mathrm{~min}, 28$ cycles of $30 \mathrm{~s}$ each at $94^{\circ} \mathrm{C}, 1 \mathrm{~min}$ at $60^{\circ} \mathrm{C}$, $1 \mathrm{~min}$ at $72^{\circ} \mathrm{C}$ and a $5 \mathrm{~min}$ final step at $72^{\circ} \mathrm{C}$ was used. Preamplified DNA was diluted 15 times and $2.5 \mathrm{~mL}$ were used for the selective amplification, which was initially performed as described by Costa et al. (2000). A protocol that included a touch down in the annealing step, and then fixed annealing temperatures were tested (50, 52.5, 55, 57.5, 60 and $62.5^{\circ} \mathrm{C}$ ) for each of the 12 primer combinations used.

Aliquots of $2 \mu \mathrm{L}$ of ISSR and SAMPL PCR products were combined with $9.75 \mu \mathrm{L}$ deionized formamide and $0.25 \mu \mathrm{L}$ LIZ-500 (molecular weight marker) for capillary electrophoresis using an $\mathrm{ABI}$ 3130xl automatic sequencer (Applied Biosystems). Raw fluorescent ISSR and SAMPL data analysis were performed by Gene Mapper 4.0 software.

ISSR and SAMPL analyses. Polymorphic fragments from ISSR and SAMPL markers were scored according to presence or absence (1 or 0 respectively) of bands in parents and offspring. Fragments were numbered relative to their molecular weight from bottom (low molecular weight) to top (high molecular weight). Segregation analysis was performed for each selected polymorphic fragment by chisquare test with $95 \%$ confidence level and segregation distortion was recorded.

\section{RESULTS}

ISSR markers. Optimum annealing temperature and $\mathrm{MgCl}_{2}$ concentration in the assays were identical for both ISSR markers $\left(46^{\circ} \mathrm{C}\right.$ and $1.25 \mathrm{mM}$ ). DNA concentration and primer annealing temperature were critical factors to obtain good banding pattern quality. Three DNA concentrations were analyzed 10, 20 and $30 \mathrm{ng}$, obtaining the best results with $10 \mathrm{ng}$ of template DNA (figure 1).

Banding patterns were clear and reproducible but they were difficult to analyze in related individuals of $P$. radiata showing no polymorphism between parentals, due to the low resolution in agarose gels. Nevertheless, the differen- 


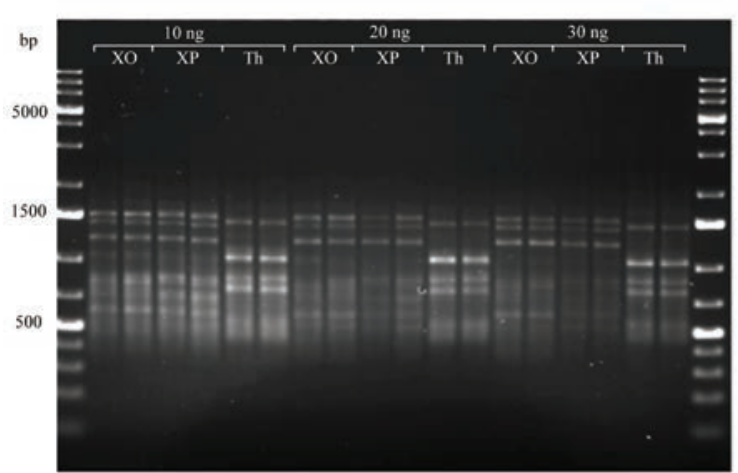

Figure 1. Effect of DNA concentration on PCR reaction. Amplified fragments with ISSR6 visualized on $1 \%$ agarose gel. Samples are shown in duplicate. XO and XP, $P$. radiata parental samples. Th, $P$. tecunumanii sample. M, 1 kb molecular weight marker.

Efecto de la concentración de ADN en la reacción de PCR. Fragmentos amplificados con ISSR 6 visualizados en un gel de agarosa $(1 \%)$. Las muestras se presentan en duplicado. XO y XP, corresponden a muestras de los parentales de $P$. radiata. Th, muestra de $P$. tecunumani. $\mathrm{M}$, marcador de peso molecular $1 \mathrm{~kb}$. ce between fragment profiles of $P$. radiata and $P$. tecunumanii were evident (figure 1).

The two labeled ISSR markers produced a total of 18 polymorphic loci on radiata pine parentals (table 1 ), which segregated in the progeny. ISSR6 gave 10 polymorphic fragments, half of them with segregation distortion, while only one of a total of eight polymorphic fragments obtained by ISSR3 showed segregation distortion.

SAMPL markers. The annealing temperature was a critical factor on the quality of banding patterns obtained from SAMPL markers. Lower temperatures favored short fragment amplification, whilst at higher temperatures amplification of larger fragments was favored (figure 2). The total number of amplified fragments (labeled and non-labeled) increased at higher annealing temperature (figure 2), however the number and intensity of amplified fragments (labeled with flourochrome) decreased at higher annealing temperatures (figure 3).

The adjustment of the annealing temperature allowed detecting a larger number of polymorphic loci for each

Table 1. Summary information for each primer combination. Información resumida para cada combinación de partidores.

\begin{tabular}{|c|c|c|c|c|c|}
\hline \multicolumn{3}{|c|}{ Primer combination } & Polymorphic fragment & Annealing temperature & Segregation \\
\hline \multicolumn{3}{|c|}{ ISSR3 } & 8 & 46.0 & 12.5 \\
\hline \multicolumn{3}{|c|}{ ISSR6 } & 10 & 46.0 & 50.0 \\
\hline \multirow{8}{*}{ 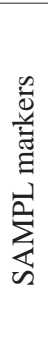 } & \multirow{7}{*}{ ISSR6 } & $\mathrm{M}+\mathrm{AGTG}$ & 14 & 55.0 & 28.6 \\
\hline & & $\mathrm{M}+\mathrm{AGCT}$ & 10 & 52.5 & 20.0 \\
\hline & & $\mathrm{M}+\mathrm{AGAC}$ & 9 & 52.5 & 11.1 \\
\hline & & M+AGGC & 8 & 52.5 & 25.0 \\
\hline & & $\mathrm{M}+\mathrm{CCTG}$ & 10 & 57.5 & 20.0 \\
\hline & & $\mathrm{M}+\mathrm{CCAT}$ & 12 & 52.5 & 33.3 \\
\hline & & $\mathrm{M}+\mathrm{CCAC}$ & 12 & 52.5 & 8.3 \\
\hline & ISSR3 & M+AGTG & 10 & 57.5 & 30.0 \\
\hline & \multicolumn{2}{|c|}{ Total } & 103 & & - \\
\hline
\end{tabular}

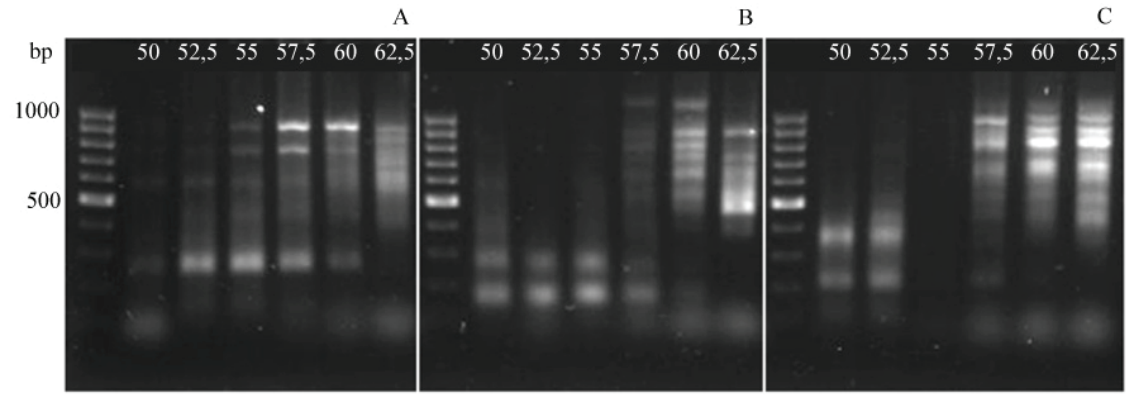

Figure 2. Annealing temperature gradient for different SAMPL combinations on $1 \%$ agarose gel. From left to right: A, ISSR6+MAGTG. B, ISSR6+MAGCT and C, ISSR6+MAGAG. M, 100 bp molecular weight marker.

Gradiente de temperatura de alineamiento para diferentes combinaciones de SAMPL visualizados en un gel de agarosa (1\%). De izquierda a derecha: A, ISSR6+MAGTG. B, ISSR6+MAGCT y C, ISSR6+MAGAG. M, marcador de peso molecular 100 bp. 
combination, while when using the protocol of Costa et al. (2000), this polymorphism was absent in the parental samples for all primer combinations tested (data not shown).

When a fixed annealing temperature was used for each primer combination, a total of 85 polymorphic fragments on radiata pine parental were found for the 8 combinations assayed (table 1), most of these were observed when using ISSR6+MAGTG (14 polymorphic fragments) and a few, in the case of ISSR6+MAGGC (6 fragments). A total of 19 fragments presented segregation distortion, representing $22.3 \%$ from the total polymorphic fragments.

\section{DISCUSSION}

DNA concentration was a critical factor in the banding pattern quality, low DNA concentrations in the amplification reaction improved fragment quality, especially for fragments between 400 and 1,000 bp (figure 1), which can be attributed to the presence of polymerase chain reaction inhibitor(s) in the samples that decreased when less

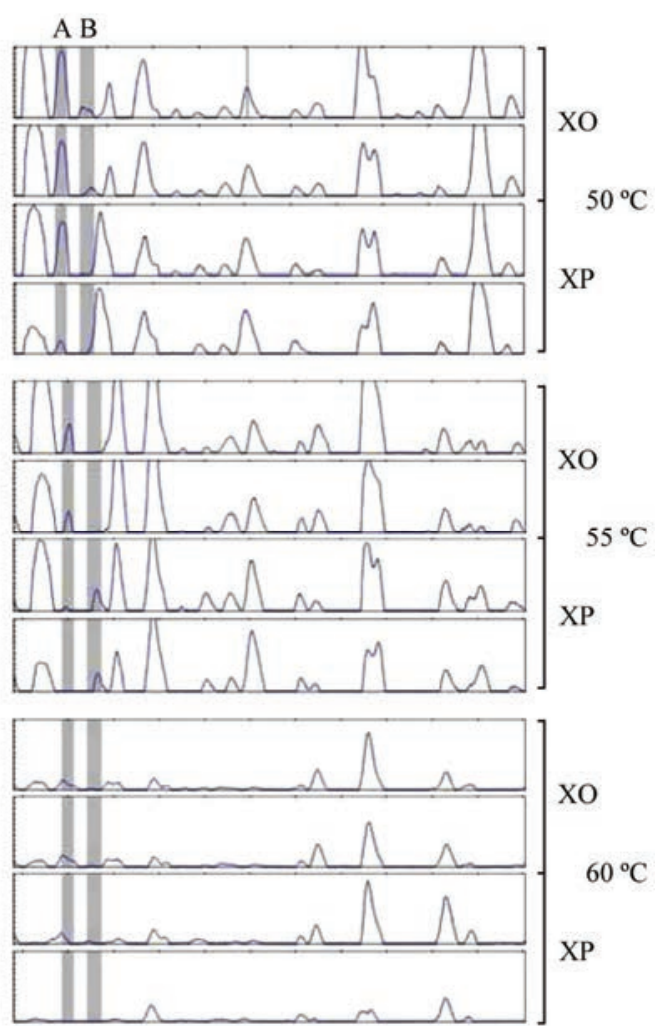

Figure 3. Optimization of annealing temperature for ISSR6+MAGTG combination visualized by capillary electrophoresis. Only three of six annealing temperatures tested are shown. Grey bars (A and B) indicate independent polymorphic band sites.

Optimización de la temperatura de alineamiento para la combinación ISSR6+MAGTG visualizada mediante electroforesis capilar. Se muestran tres de seis temperaturas de alineamiento probadas. Barras en gris (A y B) indican sitios de bandas polimórficas independientes.
DNA was employed for the reaction, thus reaction would be developed in an optimal way (McPherson and Moller 2001). The presence of smears was observed at lower annealing temperatures, which were not always eliminated by decreasing the polymerase chain reaction product volume loaded on the agarose gel, as indicated by Bornet and Branchard (2001). A possible explanation for this is the less specific hybridization of primers to the DNA template at lower temperatures, increasing annealing sites and number of amplified fragments, resulting on a smear.

The differences observed in the fragment profiles obtained for $P$. radiata and $P$. tecunumani showed that these ISSR markers can be useful for future genetic diversity studies among species of the same genus without the need of fluorochrome labeling, as reported in other plant studies (Bornet and Branchard 2001, Davila et al. 2007, Lin et al. 2010). Nevertheless, among the same species and when analyzing related individuals, visualization and the analysis of fragments using agarose gels were difficult. In this case, capillary electrophoresis presented advantages (Liu and Chen 2000), improving resolution and presenting clear and precise band detection.

Most loci with segregation distortion observed with ISSR6 can be explained because a F1 family was used, lacking breeding antecedents, which would influence the distortion ratio in the population under study (Plomion et al. 2007). Additionally, ISSR6 amplified fragments between 400 and 1,000 bp, which were out of the molecular weight range where the sequencer will work correctly using the molecular weight standard LIZ500 (35 and $500 \mathrm{bp}$ ), produced errors in allele scoring. This problem can be solved by using another molecular weight marker with a wider range.

The amplification of short fragments favored by low temperatures in SAMPL can be explained because the theoretical annealing temperature for ISSR primers $\left(46^{\circ} \mathrm{C}\right.$ ) is lower than the one required for the $\mathrm{M}+4$ primers $\left(55-60^{\circ} \mathrm{C}\right.$ ), thus these short fragments would have ISSR/ ISSR and M+4/ISSR ends. Contrastingly, at higher temperatures fragments of a longer length were observed with $\mathrm{M}+4 / \mathrm{M}+4$ ends.

Using a touch down temperature in the annealing step (Costa et al. 2000) ensures the amplification of all possible sites in the DNA, explaining why polymorphic loci were not detected in the parents studied. In the present study, applying a specific annealing temperature for each ISSR-M+4 on the selective step allowed the detection of polymorphic loci on parentals of radiata pine. Temperatures near to $50{ }^{\circ} \mathrm{C}$ masked polymorphic bands, due to unspecific hybridization of primers on the DNA samples (figure 3). A peak (figure 3A) was present in both replicates of the parent $\mathrm{XO}$, but for XP, the peak in one sample has a much higher intensity than in the other sample, making it difficult to determine the presence/absence of the polymorphism between both genotypes. This problem was solved when the optimal annealing temperature of $55^{\circ} \mathrm{C}$ 
was reached. At higher temperatures $\left(60^{\circ} \mathrm{C}\right)$, the primer hybridization is not favored and therefore lower numbers and peak intensities are observed.

The $22.3 \%$ of segregation distortion detected can be due to band co-migration, on which two or more different loci generate bands of a similar or same size (Plomion et al. 1995). Studies in the same species have detected up to $34 \%$ of segregation distortion (Kuang et al. 1999), however the smaller number of offspring compared to earlier studies (Wilcox et al. 2001, Devey et al. 2004) could be responsible for the low representativeness of the expected allelic proportions.

ISSR and SAMPL markers have not been developed for $P$. radiata. These markers were selected due to their multi-loci characteristics, which should allow the detection of most polymorphic loci by primer combination (Roy et al. 2002), and its higher reproducibility compared to random amplified polymorphic DNA (Semagn et al. 2006), producing a higher polymorphic loci number starting from small DNA samples (10-50 ng). Co-dominant markers, such as simple sequence repeat and single-nucleotide polymorphism are more informative, but they are comparatively more expensive and require prior sequence information to develop specific primers to amplify marker loci (Fisher et al. 1998, Dillon et al. 2010), while ISSR and SAMPL markers are less informative per locus (dominant markers), but yield more polymorphic loci from each primer combination (Semagn et al. 2006). The efficiency of ISSR and SAMPL markers allows a fast method to obtain fragment profiles to be employed in genetic diversity analyses, paternity tests, somaclonal variation or genetic linkage studies on $P$. radiata, where dominant markers are useful to obtain high density genetic maps, giving a framework in which more informative markers (simple sequence repeat and single-nucleotide polymorphism) can be anchored.

\section{ACKNOWLEDGMENTS}

This work was financed by Genómica Forestal (CORFO, grant number 05CTE04-02) and Comisión Nacional de Ciencia y Tecnología [CONICYT, grant number 23100216).

\section{REFERENCES}

Arcade A, F Anselin, P Faivre, M Lesage, L Paques, D Prat. 2000. Application of AFLP, RAPD and ISSR markers to genetic mapping of European larch and Japanese larch. Theoretical and Applied Genetics 100: 299-307.

Bornet B, M Branchard. 2001. Nonanchored Inter Simple Sequence Repeat (ISSR) markers: Reproducible and specific tools for genome fingerprinting. Plant Molecular Biology Reporter 19: 209-215.

Chagné D, P Chaumeil, A Ramboer, C Collada, A Guevara, M Cervera, G Vendramin, V Garcia, J-M Frigerio, C Echt, T Richardson, C Plomion. 2004. Cross-species transferability and mapping of genomic and cDNA SSRs in pines. Theoretical and Applied Genetics 109: 1204-1214.

Costa P, D Pot, C Dubos, J Frigerio, C Pionneau, C Bodenes, E Bertocchi, M Cervera, D Remington, C Plomion. 2000. A genetic map of Maritime pine based on AFLP, RAPD and protein markers. Theoretical and Applied Genetics 100: 39-48.

Dávila M, M Castillo, H Laurentin. 2007. Uso de marcadores moleculares ISSR para inferir las relaciones genéticas y la variabilidad intraespecífica en Agave. Revista de la Facultad de Agronomía 33: 93-111.

Devey M, J Bell, T Uren, G Moran. 2002. A set of microsatellite markers for fingerprinting and breeding applications in $\mathrm{Pi}$ nus radiata. Genome 45: 984-989.

Devey M, K Groom, M Nolan, J Bell, M Dudzinski, K Old, A Matheson, G Moran. 2004. Detection and verification of quantitative trait loci for resistance to Dothistroma needle blight in Pinus radiata. Theoretical and Applied Genetics 6: 1056-1063.

Dillon S, M Nolan, W Li, C Bell, H Wu, S Southerton. 2010. Allelic variation in cell wall candidate genes affecting solid wood properties in natural populations and land races of Pinus radiata. Genetics 185: 1477-1487.

Fisher PJ, RC Gardner, TE Richardson. 1998. Characteristics of single- and multi-copy microsatellites from Pinus radiata. Theoretical and Applied Genetics 96: 969-979.

Kuang H, TE Richardson, SD Carson, PL Wilcox, B Bongarten. 1999. Genetic analysis of inbreeding depression in plus tree 850.055 of Pinus radiata D. Don. 1. Genetic map with distorted markers. Theoretical and Applied Genetics 98: 697-703.

Leroy X, K Leon, M Branchard. 2000. Plant genomic instability by microsatellite-primers. Electronic Journal of Biotechnology 3 (2): 140-148.

Lin X, Y Lou, J Liu, J Peng, G Liao, W Fang. 2010. Crossbreeding of Phyllostachys species (Poaceae) and identification of their hybrids using ISSR markers. Genetics and Molecular Research 9 (3): 1398-1404.

Liu MS, FT Chen. 2000. Rapid analysis of amplified doublestranded DNA by capillary electrophoresis with laserinduced fluorescence detection. Molecular Biotechnology 15:143-146.

McPherson M, S Moller. 2001. PCR. New York, USA. BIOS Scientific Publishing. 288 p.

Morgante M and J Vogel. 1994. Compound microsatellite primers for the detection of genetic polymorphisms. US patent application no. 08/326456.

Okun D, E Kenya, P Oballa, D Odee, G Muluvi. 2008. Analysis of genetic diversity in Eucalyptus grandis (Hill ex Maiden) seed sources using inter simple sequence repeats (ISSR) molecular markers. African Journal of Biotechnology 7(13): 2119-2123.

Paglia G, M Morgante. 1998. PCR-based multiplex DNA fingerprinting techniques for the analysis of conifer genomes. Molecular Breeding 4: 173-177.

Paglia GP, AM Olivieri, M Morgante. 1998. Towards secondgeneration STS (sequence-tagged sites) linkage maps in conifers: a genetic map of norway spruce (Picea abies K.). Molecular Genetics and Genomics 258: 466-478.

Plomion C, N Bahrman, C Durel. D O’Malley. 1995. Genomic mapping in Pinus pinaster (maritime pine) using RAPD and protein markers. Heredity 74: 661-668. 
Plomion C, D Chagné, D Pot, S Kumar, P Wilcox, R Burdon, D Prat, D Peterson, J Paiva, P Chaumeil, G Vendramin, F Sebastiani, C Nelson, C Echt, O Savolainen, T Kubisiak, M Cervera, N De María, M Islam-Faridi. 2007. Pines. In Kole $\mathrm{C}$ ed. Genome mapping and molecular breeding in plants. Berlin, Germany. Springer-Verlag. p. 29-92.

Roy J, H Balyan, M Prasad, P Gupta. 2002. Use of SAMPL for a study of DNA polymorphism, genetic diversity and possible gene tagging in bread wheat. Theoretical and Applied Genetics 104: 465-472.

Semagn K, A Bjornstad, MN Ndjiondjop. 2006. An overview of molecular marker methods for plants. African Journal of Biotechnology 5(25): 2540-2568.

Sorensson C and C Shelbourne. 2005. Clonal forestry. In Colley M ed. Forestry Handbook. NZ Inst. of Foresters. p. 92-96.

Wilcox P, T Richardson, G Corbet, R Ball, J Lee, A Djorovic, S Carson. 2001. Framework Linkage Maps of Pinus radiata D. Don based on pseudotestcross markers. Forest Genetics 8: 109-117.

Zietkiewicz E, A Rafalski, D Labuda. 1994. Genome fingerprinting by simple sequence repeats (SSR)-anchored PCR amplification. Genomics 20: 176-183.

Recibido: 13.12 .10

Aceptado: 15.11 .11 